Case report

\title{
Eosinophilic Gastroenteritis with Acute Abdomen: A Case Report
}

\author{
Tahmineh Biazar, Parisa Sabbagh, Soheil Ebrahimpour, Masomeh Bayani \\ Infectious Diseases and Tropical Medicine Research Center, Health Research Institute, \\ Babol University of Medical Sciences, Babol, I.R. Iran
}

\section{SUMMARY}

Eosinophilic gastroenteritis (EGE) as a rare inflammatory gastrointestinal (GI) disorder is primarily characterized by long-term or recurrent abdominal pain. Peripheral eosinophilia is usually caused by eosinophilic infiltrations into the multiple layers of the GI tract. In this report, a case of EGE with an acute abdomen is presented. A 14-year-old female experienced severe abdominal pain and hypereosinophilia. She underwent appendectomy due to severe abdominal pain approximately one week before readmission. Because of the persistence of pain, the upper GI endoscopy and biopsy were performed and the result of the pathological examination was eosinophilic gastroenteritis. Due to the nonspecificity of EGE symptoms, it is recommended that clinicians study pathology in atypical and nonresponsive GI diseases; biopsy should be performed as well.

Key words: eosinophilia, gastroenteritis, acute abdomen, endoscopy, biopsy 


\section{INTRODUCTION}

Eosinophilic gastroenteritis (EGE) is a rare gastrointestinal (GI) inflammatory disorder that affects all ages (1). This infrequent disorder is characterized by long-term or recurrent abdominal pain, diarrhea, nausea, vomiting, gastrointestinal bleeding, and weight loss (2). EGE may cause esophagitis, enteritis, gastritis, gastroenteritis, and eosinophilic colitis $(3,4)$. Peripheral eosinophilia can be caused by eosinophil infiltrations in some layers of the GI tract (1).

Thus, the clinical presentation varies with the site of GI involvement and the depth of the intestinal wall involvement. According to another classification, the infiltration occurs at the mucosal layer, muscle layer, or the subserosal layer (5). Because of the variety of clinical manifestations, the differential diagnosis of severe and chronic abdominal pain is considered as an important problem. Herein we describe a case of EGE involving the abdomen.

\section{CASE REPORT}

A 14-year-old female presented to the emergency department with severe and generalized abdominal pain. In addition, she denied any past medical history.

Open appendectomy was performed in this case according to the criteria for diagnosing acute appendicitis.

After ten days, the recurrent pain was localized in certain areas of the abdomen, particularly in the epigastrium. Then, the patient was admitted to our center and underwent the diagnostic work-up.

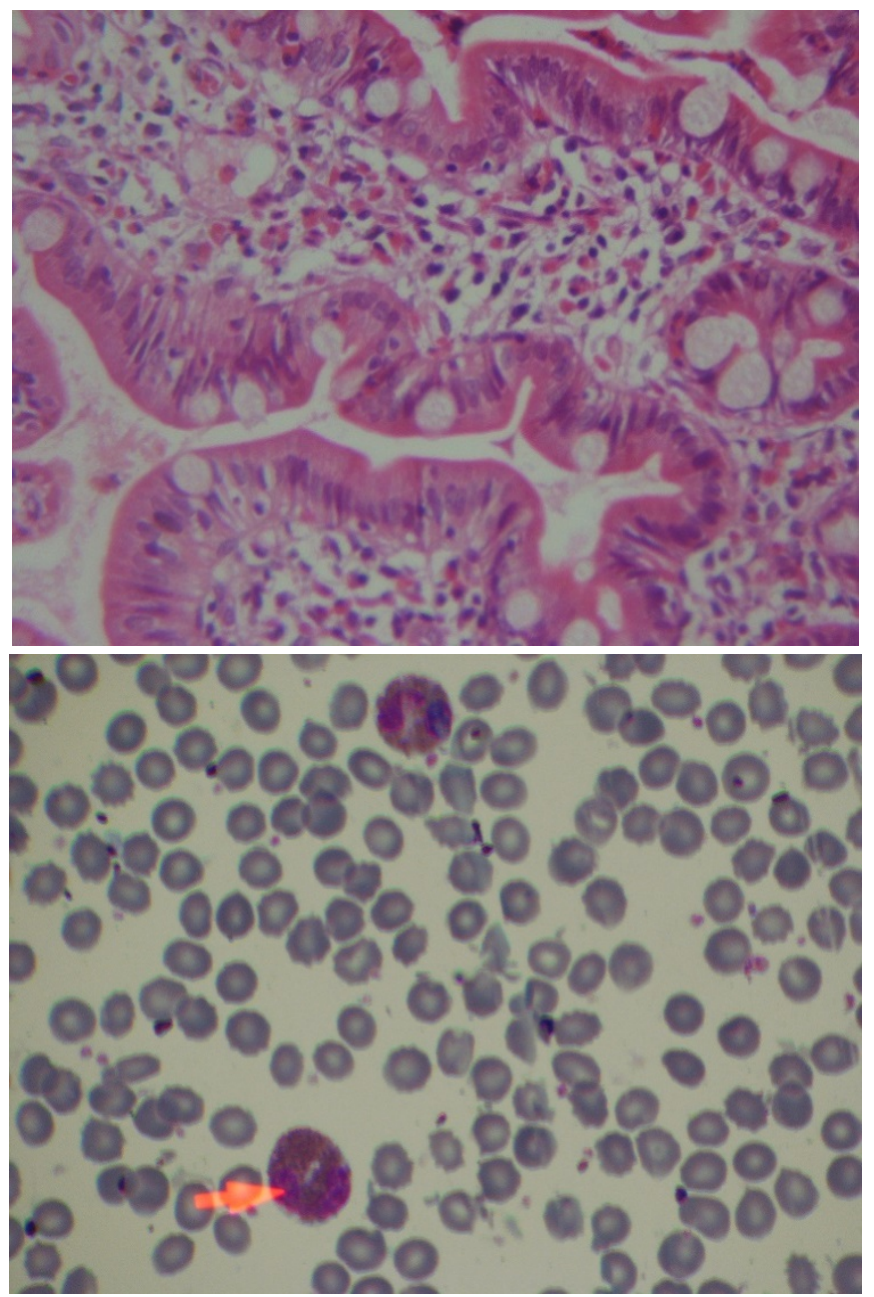

Figure 1: Histology of duodenal tissue revealed that massive eosinophilic infiltration (hematoxylin $\mathcal{E}$ eosin stain; magnification $\times 100$ ) 
Her vital signs were normal, however, epigastric rebound tenderness was found. She was diagnosed with seasonal allergic rhinitis by reviewing her medical history. Also, there was not a history of asthma or food allergy. Her blood test results showed that the white blood cell (WBC) count was $24,400 / \mu \mathrm{L}$ with marked eosinophilia of $60 \%$ and an absolute number of eosinophils in excesses of 14640 cells $/ \mu \mathrm{L}$. Other laboratory data such as amylase, lipase, electrolytes, and liver function tests (LFTs) were normal. Ultrasound assessment of this patient found no masses or fluids.

Due to the persistence of pain, the upper GI endoscopy was performed and revealed erythema on the distal esophagus and erythematous nodularity from the first to the second part of the duodenum; the biopsy was also taken. Duodenal tissue histology showed massive eosinophilic infiltration without EGE indication (Figure 1). Treatment with ketotifen and montelukastwas started and continued for the next two months. There were no complications and symptoms in the follow-up period in this case.

\section{DISCUSSION}

EGE is a rare disorder that was first recognized in 1937 and is characterized by severe eosinophilic infiltration into the GI tract and is generally associated with the peripheral eosinophilia (6). As a result, peripheral eosinophilia is frequently observed (over 80\%) (7). Eosinophils can mediate the modulation of the cellular activation states by releasing the molecules like IL-2, IL-4, IL-5, IL-10, IL12, IL-13, RANTES and platelet-activating factor (PAF) (8). Additionally, these cells can serve as the primary effector cells, inducing tissue damage and dysfunction by releasing lipid mediators as well as toxic granule proteins, including eosinophil peroxidase (EPO), major basic protein (MBP), eosinophilic cationic protein $(\mathrm{ECP})$, and eosinophil-derived neurotoxin (EDN) (9).
The importance of this case lies in the high levels of eosinophils and acute abdomen as atypical presentation. The endoscopic results are non-specific and must be considered in cases without response to routine treatment and peripheral eosinophilia. As in our patient, histopathologic results revealed severe chronic gastritis, moderate activity of lymphoid aggregation, and numerous eosinophils. Also, as in our patient, the EGE in other cases has been confirmed with histopathological findings (10).

The diagnosis of the EGE is based on the exclusion of other causes of eosinophilia such as lymphoma, parasitic infection, carcinomas, inflammatory bowel disease (IBD) and allergy (11). In this disorder, about half of all cases have accompanying allergic diseases such as asthma, allergic rhinitis, urticaria, eczema, and drug reaction (12). Also, the pathogenesis points to hypersensitivity; however, food allergy is not a causal factor of EGE (13). The same was found in our patient.

The low doses of antihistamine agents, corticosteroids, and anti leukotriene drugs are the main therapy for this disease, however, the duration of treatment is not well-defined (5). In this patient, the symptoms eventually withdrew after 8 weeks of treatment with antihistamine and montelukast, without any recurrence. In conclusion, because of the non-specificity of EGE symptoms, clinicians must consider this pathology in atypical and non-responsive GI diseases; biopsy must be performed as well.

\section{Acknowledgements}

The authors thank to the Department of Infectious diseases of Babol University of Medical sciences, Iran.

\section{Conflict of interests}

All of authors report no conflict of interest. 


\section{References}

1. Ingle SB, Hinge Ingle CR. Eosinophilic gastroenteritis: an unusual type of gastroenteritis. World J Gastroenterol 2013;19(31):5061-6. https://doi.org/10.3748/wjg.v19.i31.5061

2. Mori A, Enweluzo C, Grier D, Badireddy M. Eosinophilic gastroenteritis: review of a rare and treatable disease of the gastrointestinal tract. Case Rep Gastroenterol 2013;7(2):293-8. https://doi.org/10.1159/000354147

3. Cianferoni A, Spergel JM. Eosinophilic Esophagitis and Gastroenteritis. Curr Allergy Asthma Rep 2015;15(9):58.

https://doi.org/10.1007/s11882-015-0558-5

4. Prussin C. Eosinophilic gastroenteritis and related eosinophilic disorders. Gastroenterol Clin North America 2014;43(2):317-27.

https://doi.org/10.1016/j.gtc.2014.02.013

5. AbouRached A, El Hajj W. Eosinophilic gastroenteritis: Approach to diagnosis and management. World J gastroint Pharmacol Ther 2016;7(4):513-23.

https://doi.org/10.4292/wjgpt.v7.i4.513

6. Gonsalves N, Furuta GT, Atkins D. Eosinophilic Gastrointestinal Disorders Affect More Than Just the Esophagus. J Pediatr Gastroenterol Nutr 2016;62(1):1-2.

https://doi.org/10.1097/MPG.0000000000000993

7. Abassa K-K, Lin X-Y, Xuan J-Y, Zhou H-X, Guo Y$\mathrm{W}$. Diagnosis of eosinophilic gastroenteritis is easily missed. World J Gastroenterol 2017;23(19):3556-64. https://doi.org/10.3748/wjg.v23.i19.3556

8. Hogan SP. Functional role of eosinophils in gastrointestinal inflammation. Immunol Allergy Clin North Am 2009;29(1):129-xi.

https://doi.org/10.1016/j.iac.2008.10.004

9. Acharya KR, Ackerman SJ. Eosinophil granule proteins: form and function. J Biol Chem 2014;289(25):17406-15.

https://doi.org/10.1074/jbc.R113.546218

10. López-Medina G, Gallo M, Prado A, VicuñaHonorato I, Castillo Díaz de León R. Eosinophilic Gastroenteritis: Case Report and Review in Search for Diagnostic Key Points. Case Rep Gastrointestinal Med 2015;2015:239506.

https://doi.org/10.1155/2015/239506

11. Freeman HJ. Adult eosinophilic gastroenteritis and hypereosinophilic syndromes. World J Gastroenterol 2008;14(44):6771-3.

https://doi.org/10.3748/wjg.14.6771

12. Ishihara S, Kinoshita Y, Schoepfer A. Eosinophilic Esophagitis, Eosinophilic Gastroenteritis, and Eosinophilic Colitis: Common Mechanisms and Differences between East and West. Inflamm Intest Dis 2016;1(2):63-9.

https://doi.org/10.1159/000445131

13. Yu W, Freeland DMH, Nadeau KC. Food allergy: immune mechanisms, diagnosis and immunotherapy. Nat Rev Immunol 2016;16(12):751-65.

https://doi.org/10.1038/nri.2016.111 


\title{
Eozinofilni gastroenteritis sa akutnim abdomenom: prikaz slučaja
}

\author{
Tahmineh Biazar, Parisa Sabbagh, Soheil Ebrahimpour, Masomeh Bayani \\ Istraživački centar za infektione i tropske bolesti, Zdravstveni istraživački institut, \\ Univerzitet medicinskih nauka u Babolu, Babol, Iran
}

\section{S A ŽETAK}

Eozinofilni gastroenteritis (EGE) kao redak inflamatorni gastrointestinalni (GI) poremećaj, primarno se karakteriše dugotrajnim ili rekurentnim bolom u abdomenu. Periferna eozinofilija je obično izazvana prisustvom eozinofilnih infiltrata u slojevima gastrointestinalnog trakta. $U$ ovom radu je prikazan slučaj eozinofilnog gastroenteritisa sa akutnim abdomenom. Četrnaestogodišnjakinja je imala jake bolove u predelu abdomena i hipereozinofiliju. Zbog jakih bolova u abdomenu podvrgnuta je apendektomiji, nedelju dana pre prijema u bolnicu. Zbog perzistentnog bola, urađene su endoskopija gornjih partija gastrointestinalnog trakta i bopsija i rezultat patološkog ispitivanja ukazao je na eozinofilni gastroenteritis. Zbog nespecifičnosti simptoma eozinofilnog gastroenteritisa, kliničarima se preporučuje razmatranje patologije kod atipičnih i neizlečivih bolesti gastrointestinalnog trakta. Takođe, treba uraditi i biopsiju.

Ključne reči: eozinofilija, gastroenteritis, akutni abdomen, endoskopija, biopsija 